\title{
The effect of the pro-inflammatory cytokine tumor necrosis factor-alpha on human joint capsule myofibroblasts
}

\author{
Stefan G Mattyasovszky*+1, Alexander Hofmann ${ }^{+1}$, Christoph Brochhausen2, Ulrike Ritz'1, Sebastian Kuhn1, \\ Jochen Wollstädter ${ }^{1}$, Hendrik Schulze-Koops ${ }^{3}$, Lars P Müller'1, Bernhard Watzer ${ }^{4}$ and Pol M Rommens ${ }^{1}$
}

\begin{abstract}
Introduction: Previous studies have shown that the number of myoblastically differentiated fibroblasts known as myofibroblasts (MFs) is significantly increased in stiff joint capsules, indicating their crucial role in the pathogenesis of post-traumatic joint stiffness. Although the mode of MFs' function has been well defined for different diseases associated with tissue fibrosis, the underlying mechanisms of their regulation in the pathogenesis of post-traumatic joint capsule contracture are largely unknown.

Methods: In this study, we examined the impact of the pro-inflammatory cytokine tumor necrosis factor-alpha (TNF-a) on cellular functions of human joint capsule MFs. MFs were challenged with different concentrations of TNF-a with or without both its specifically inactivating antibody infliximab (IFX) and cyclooxygenase-2 (COX2) inhibitor diclofenac. Cell proliferation, gene expression of both alpha-smooth muscle actin (a-SMA) and collagen type l, the synthesis of prostaglandin derivates $E_{2}, F_{1 A}$ and $F_{2 A}$ as well as the ability to contract the extracellular matrix were assayed in monolayers and in a three-dimensional collagen gel contraction model. The a-SMA and COX2 protein expressions were evaluated by immunofluorescence staining and Western blot analysis.

Results: The results indicate that TNF-a promotes cell viability and proliferation of MFs, but significantly inhibits the contraction of the extracellular matrix in a dose-dependent manner. This effect was associated with downregulation of a-SMA and collagen type / by TNF-a application. Furthermore, we found a significant time-dependent upregulation of prostaglandin $\mathrm{E}_{2}$ synthesis upon TNF-a treatment. The effect of TNF-a on COX2-positive MFs could be specifically prevented by IFX and partially reduced by the COX2 inhibitor diclofenac.

Conclusions: Our results provide evidence that TNF-a specifically modulates the function of MFs through regulation of prostaglandin $\mathrm{E}_{2}$ synthesis and therefore may play a crucial role in the pathogenesis of joint capsule contractures.
\end{abstract}

\section{Introduction}

Post-traumatic joint stiffness is a common complication that occurs primarily after injuries of the upper extremities involving articular structures $[1,2]$. In the majority of cases, loss of function after trauma is due to adhesions and contractions as well as to scar formation within capsulo-ligamentous structures. Upon injury, fibroblasts of the surrounding tissue become activated, start to proliferate, and undergo a phenotypic differentiation into contractile

\section{* Correspondence: Stefan.Mattyasovszky@gmx.de}

Department of Trauma and Orthopaedic Surgery, Johannes Gutenberg University School of Medicine, Langenbeckstr. 1, 55101 Mainz, Germany

+Contributed equally myofibroblasts (MFs) [3]. Differentiated MFs are characterized by the expression of alpha-smooth muscle actin ( $\alpha$ SMA), a protein that is associated with the contractile phenotype of this cell type [4-6], as well as the synthesis of proteins over the course of the healing process [5-8]. Although the underlying mechanisms of joint capsule contracture are still poorly understood on the cellular level, the activation and differentiation of MFs seem to be controlled by a complex tissue-specific network of growth factors and cytokines [3,9]. Mechanical stress, ED-A (extra domain A) fibronectin, and transforming growth factor-beta 1 (TGF$\beta 1)$ are potent inducers of $\alpha$-SMA expression and thus are considered to be pro-fibrotic factors $[3,5,6,10,11]$. The 
complex interaction of different growth factors, cytokines, and extracellular matrix (ECM) may create an environment with an abnormal cytokine profile, which triggers the excessive formation of MFs followed by high matrix turnover. In this context, numerous fibroconnective disorders $[8,10]$ such as Dupuytren contracture [12,13], carpal tunnel syndrome [14], and frozen shoulder [15] have been associated with the appearance of MFs.

Until now, it has not been clear whether a specific inhibition of certain cytokines would be beneficial for prevention of unrestricted MF activation. The pro-inflammatory cytokine tumor necrosis factor-alpha (TNF- $\alpha$ ) has aroused our interest as a potential target molecule since the results of recent studies have demonstrated its antagonistic activity against the pro-fibrotic factor TGF- $\beta 1$ [16-18]. These findings, however, still need further confirmation as the effect of TNF- $\alpha$ may be site- as well as organ-specific. TNF- $\alpha$ may exert direct cellular effects on TGF- $\beta 1$ expression, as shown by Sullivan and colleagues [19] for lung fibroblasts. Moreover, TNF- $\alpha$ is capable of regulating the activity of cardiac fibroblasts by decreasing collagen synthesis and increasing matrix metalloproteinase activity [20]. However, the role of this pleiotropic cytokine has not yet been defined in the pathogenesis of post-traumatic joint contracture. Based on the current data, we hypothesized that TNF- $\alpha$ is likely to modulate the proliferation, differentiation, and function of human joint capsule MFs and therefore may unveil new therapeutic approaches for the prevention and treatment of post-traumatic joint contracture. Here, we describe the effect of TNF- $\alpha$ and its specific inhibitor infliximab (IFX) on human MFs under controlled in vitro conditions. We also report that the positive regulation of prostaglandin $\mathrm{E}_{2}\left(\mathrm{PGE}_{2}\right)$ by TNF- $\alpha$ may play an important role in the regulation of human joint capsule MF function.

\section{Materials and methods}

Human hip joint capsules were taken from 12 adult patients (10 women and 2 men) with a mean age of 73 years (range 58 to 96$)$ undergoing orthopedic surgery. The original injuries were either displaced femoral neck fractures $(n=6)$ or advanced osteoarthritis $(\mathrm{n}=6)$ treated with hemi-hip or total hip replacement. Physical examination in terms of the range of motion (ROM) of the hip joints in patients with fractures was not possible. However, based on the medical history, there were no indications about restricted ROM before the injury. The six patients operated on for osteoarthritis revealed a mean ROM of the hip joint as follows: extension/flexion $0^{\circ}-0^{\circ}-108^{\circ}$, external/internal rotation $25^{\circ}$ $0^{\circ}-20^{\circ}$, and abduction/adduction $50^{\circ}-0^{\circ}-20^{\circ}$. The patients included neither were operated on before nor suffered from rheumatic diseases or any conditions known to affect wound healing.

For immunohistochemical comparison, contracted elbow joint capsules were taken from four patients ( 3 women and
1 man; mean age of 61 years, range 56 to 65 ) undergoing elbow surgery for post-traumatic stiffness. The original injuries of the elbow patients were comminuted distal humeral fractures treated primarily with open reduction and internal fixation (ORIF) with plates. All of the patients operated on had stiff elbows with severely limited ROM.

All of the functional experiments were performed with cells isolated from hip joint capsules at least in triplicate using triplicate or quadruplicate samples, whereas the number of measurements in probands varied for technical reasons. The joint capsules used for the study were considered to be surgical waste and otherwise would have been discarded by the hospital. All experiments were approved by the local ethics committee of Rheinland Pfalz (RLP 837.109.05 [4767]), and written informed consent was obtained from every participating patient.

\section{Cell isolation and culture of human myofibroblasts}

All of the cultures and functional experiments were performed with cells isolated from hip joint capsules. The joint capsules were processed within 6 hours after excision. The inner layer of the capsule, the synovial membrane, which was loosely attached to the external fibrous capsule, was carefully dissected from the fibrous tissue. For all of the experiments, the outer layer of the joint capsule with the fibrous tissue was used. The samples were rinsed in phosphate-buffered saline (PBS) (Dulbecco's PBS; Gibco Invitrogen Corporation, Karlsruhe, Germany) to remove blood and fat residues and were gradually digested in a water bath at $37^{\circ} \mathrm{C}$ with a mixture of type IV collagenase $(1 \mathrm{mg} / \mathrm{mL}$; Sigma-Aldrich Chemie GmbH, Steinheim, Germany), trypsin $(2.5 \mathrm{mg} / \mathrm{mL}$; Sigma-Aldrich Chemie $\mathrm{GmbH})$, and DNase I (deoxyribonuclease I) (2 mg/mL; Applichem $\mathrm{GmbH}$, Darmstadt, Germany). The specimens were filtered through a cell strainer $(100-\mu \mathrm{m}$ mesh; BD Biosciences, Heidelberg, Germany) after 45 and 90 minutes of incubation to obtain a single-cell suspension. The cell supernatant was washed in serum-free Dulbecco's modified Eagle's medium (DMEM) (Biochrom AG, Berlin, Germany) supplemented with $10,000 \mathrm{U} / \mathrm{mL}$ penicillin $\mathrm{G}$ sodium and $10,000 \mu \mathrm{g} / \mathrm{mL}$ streptomycin sulfate (Gibco Invitrogen Corporation, Karlsruhe, Germany) and finally centrifuged at $1.4 \times 10^{3} \mathrm{rpm}$ for 5 minutes at $4^{\circ} \mathrm{C}$. The cell pellet was resuspended in DMEM supplemented with $10 \%$ heat-inactivated fetal calf serum (FCS) (PAA Laboratories $\mathrm{GmbH}$, Pasching, Austria) and antibiotics, seeded into culture flasks (Cellstar; Greiner Bio-One GmbH, Frickenhausen, Germany), and incubated in a humidified atmosphere of 5\% $\mathrm{CO}_{2}$ at $37^{\circ} \mathrm{C}$. Culture media were changed twice a week, and preconfluent cells were passaged using accutase (PAA Laboratories $\mathrm{GmbH}$ ). Early-passage cells (passages 2 to 4 ) were used for all experiments. 


\section{Immunohistochemical evaluation of the joint capsule biopsies}

Specimens of hip joint capsules and contracted elbow joint capsules were fixed in neutral buffered formalin and embedded in paraffin, and $5 \mu \mathrm{m}$-sections were routinely stained with hematoxylin-eosin. MFs in the biopsies were detected by immunohistochemical staining for $\alpha$-SMA using a monoclonal primary mouse anti- $\alpha$-SMA antibody (dilution 1:600; Progen Biotechnik GmbH, Heidelberg, Germany; clone ASM-1) followed by a ready-to-use biotinylated secondary antibody (Dako Real ${ }^{\mathrm{TM}}$ Link; Dako, Glostrup, Denmark) and were visualized using the streptavidin-peroxidase method with 3,3'-diaminobenzidine (DAB) as chromogen. Immunohistochemical staining was performed with an automated staining system (Dako TechMate 500 PLUS; Dako) using a standard ready-to-use kit. Histological slides were evaluated under an Olympus light microscope (BX45; Olympus, Hamburg, Germany) and documented with a digital camera (Camedia C7070; Olympus).

The expression of $\alpha$-SMA in MF cultures originating from hip joint capsules was verified using a monoclonal mouse anti-human- $\alpha$-SMA antibody (Dako, Hamburg, Germany). The cells were seeded on histological cover slides at a density of 25,000 cells $/ \mathrm{cm}^{2}$, incubated for 24 hours, and fixed with $3.7 \%$ paraformaldehyde (PFA). The slides were incubated with the primary antibody for 2 hours, washed with PBS, incubated with the secondary horseradish peroxidase-coupled rabbit anti-mouse antibody (Dako), and stained with DAB. Cell nuclei were counterstained with Mayer's hemalun (Merck AG, Darmstadt, Germany). The positive cells have been counted and calculated in subconfluent cultures in five separate viewing fields under a light microscope.

Immunofluorescence analysis of cell culturesMFs $(4 \times$ $10^{4}$ cells/well) were cultured on histological cover slides with or without the cyclooxygenase-2 (COX2) inhibitor diclofenac $(10 \mu \mathrm{g} / \mathrm{mL})$ in DMEM containing $1 \% \mathrm{FCS}$. The expression of $\alpha$-SMA and COX2 in MFs was determined by immunofluorescence double-staining using a primary monoclonal mouse anti-human- $\alpha$-SMA antibody (dilution 1:50, clone 1A4; Dako; 45 minutes at room temperature) and a primary mouse anti-human-COX2 antibody (1:100 in saponin buffer, clone 33/COX2; BD Biosciences; 45 minutes at room temperature) in PFA-fixed cell cultures. Cells were washed two times with cold PBS and incubated with Texas Red-conjugated goat anti-mouse $\operatorname{IgG} 2 \mathrm{a}$ for $\alpha$-SMA followed by fluorescein isothiocyanate-conjugated goat anti-mouse IgG1 for COX2 (both from SouthernBiotech, Birmingham, AL, USA) as a secondary antibody. Negative controls were performed using respective isotype antibodies. Cell nuclei were stained with Hoechst 33258 (dilution 1:10,000; Sigma-Aldrich Chemie $\mathrm{GmbH}$ ) for 10 minutes at room temperature in all experiments. Subsequently, the slides were rinsed and embedded with Gel Mount (SouthernBiotech) on glass cover slides. Cells were visualized using a laser scanning confocal microscope (TCS SP-2; Leica Microsystems, Bensheim, Germany).

\section{Cell viability and proliferation}

MFs were seeded into 96-well plates (Greiner Bio-One $\mathrm{GmbH})$ at a density of $10 \times 10^{4}$ cells/well and incubated in $150 \mu \mathrm{L}$ of serum-supplemented DMEM ( $5 \%$ FCS, $1 \%$ penicillin/streptomycin) for 48 hours. Thereafter, the cell layers were washed with PBS and incubated for 24 hours in 150 $\mu \mathrm{L}$ of serum-free DMEM supplemented with $1 \%$ bovine serum albumin (BSA). After 24 hours, the cells were washed with PBS and incubated for 72 hours in $150 \mu \mathrm{L}$ of serum-free DMEM containing 1 or $10 \mathrm{ng} / \mathrm{mL}$ of TNF- $\alpha$ (R\&D Systems GmbH, Wiesbaden-Nordenstadt, Germany) and/or the chimeric monoclonal antibody to TNF- $\alpha(10 \mu \mathrm{g} /$ $\mathrm{mL}$ IFX, generously provided by Centocor B.V., Leiden, The Netherlands), and/or $10 \mu \mathrm{g} / \mathrm{mL}$ of the COX2 inhibitor diclofenac (Figure 1). MFs cultured in $150 \mu \mathrm{L}$ of serumfree DMEM without any cytokine or inhibitor were used as controls and named as the control group. Cell viability and proliferation were measured using the colorimetric 3-(4,5dimethylthiazol-2-yl)-2,5-diphenyl tetrazolium bromide (MTT) assay (Promega GmbH, Mannheim, Germany). After 72 hours, $30 \mu \mathrm{L}$ of $0.5 \%$ MTT solution was added to each well and incubated for 2 hours. The medium was removed, and the dye was resolved with $100 \mu \mathrm{L}$ of isopropanol (Hedinger GmbH \& Co. KG, Stuttgart, Germany). The optical density was measured at $570 \mathrm{~nm}$ (650 nm background) using an enzyme-linked immunosorbent assay reader (Sunrise; Tecan Deutschland GmbH, Crailsheim, Germany).

\section{Collagen gel contraction assay}

A three-dimensional (3D) collagen gel contraction model, which is a well-accepted method for the estimation of the cell-mediated contracture of the ECM in vitro in a $3 \mathrm{D}$ environment [21], was established to estimate the contractile forces exhibited by human hip joint MFs. The present protocol was established with primary human hip joint capsule MFs by varying cell numbers, collagen gel volumes and concentrations, time points of detachment, and different concentrations of TGF- $\beta 1$ as a positive control (data not shown) $[18,22,23]$. Due to limited numbers of primary cells from each donor, conditions requiring least possible cell numbers and collagen volumes have been used.

Collagen gels were prepared using type I rat collagen (1.5 $\mathrm{mg} / \mathrm{mL}$; BD Biosciences, Bedford, MA, USA) in a 10-fold Medium 199 concentrate, 7.5\% $\mathrm{NaHCO}_{3}, 1 \mathrm{~N} \mathrm{NaOH}$ (all from Sigma-Aldrich Chemie $\mathrm{GmbH}$ ), and distilled water. The cells were resuspended in the gel solution and seeded into 24 -well plates at a density of $1.2 \times 10^{5}$ cells $/ 300 \mu \mathrm{L}$. 


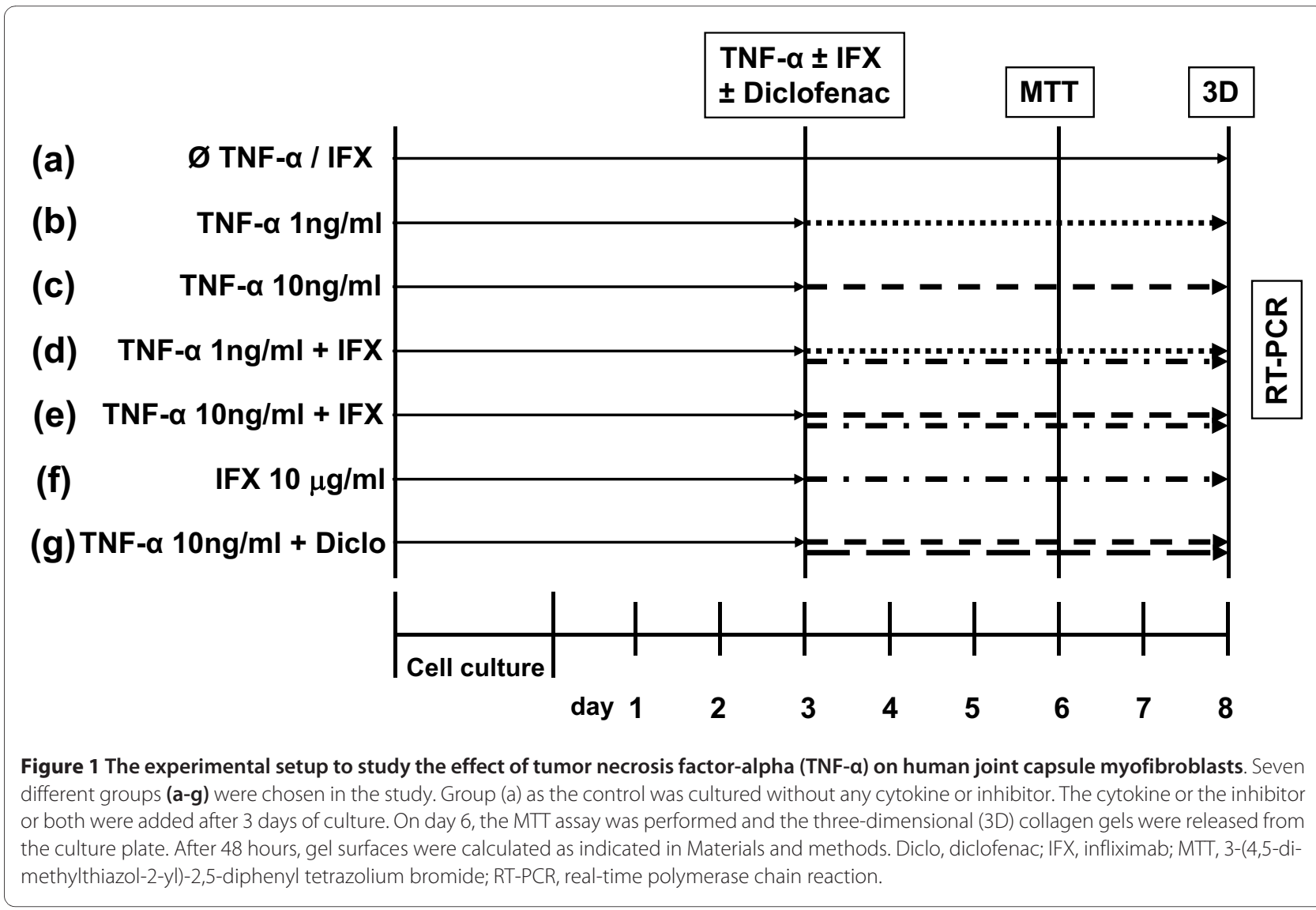

After 30 minutes, the solidified gels were incubated in 1 $\mathrm{mL}$ of serum-supplemented DMEM (10\% FCS) for 48 hours. Thereafter, the gels were washed with PBS and incubated for 24 hours in $1 \mathrm{~mL}$ of serum-free DMEM supplemented with $1 \%$ BSA. After a vigorous rinsing with PBS, the cells were incubated for 72 hours in $1 \mathrm{~mL}$ of serum-free DMEM containing TNF- $\alpha$ and/or IFX and/or diclofenac according to Figure 1. MFs incubated in $150 \mu \mathrm{L}$ of serumfree DMEM only were used as controls and named as the control group. Thereafter, the gels were released from the culture plate with a pipette tip and cultured for a further 48 hours. Gel surfaces were scanned using the Canon $660 \mathrm{U}$ scanner (Canon Deutschland GmbH, Krefeld, Germany) and calculated using the software ImageJ (National Center for Biotechnology Information, Bethesda, MD, USA).

\section{Simultaneous quantification of prostanoids using gas chromatography/mass spectrometry}

Cells were cultured under the same conditions as described in the previous section (Collagen gel contraction assay) and challenged with TNF- $\alpha$ (1 or $10 \mathrm{ng} / \mathrm{mL})$ as described above or coincubated with TNF- $\alpha(10 \mathrm{ng} / \mathrm{mL})$ and diclofenac $(10$ $\mu \mathrm{g} / \mathrm{mL}$ ) (Figure 1) after serum deprivation for 24 hours. Cell culture medium supernatants were collected after 24 , 48,72 , and 96 hours of culture and fresh medium was sub- sequently added to the cultures at these time points. The synthesis of prostaglandins $\mathrm{E}_{2}\left(\mathrm{PGE}_{2}\right), \mathrm{F}_{1 \mathrm{~A}}\left(\mathrm{PGF}_{1 \mathrm{~A}}\right)$, and $\mathrm{F}_{2 \mathrm{~A}}\left(\mathrm{PGF}_{2 \mathrm{~A}}\right)$ was determined by gas chromatography/mass spectrometry (GC/MS). Sample aliquots were kept at $-80^{\circ} \mathrm{C}$ until further analysis. Concentrations of $\mathrm{PGE}_{2}, \mathrm{PGF}_{2 \mathrm{~A}}$, and the stable prostacyclin metabolite $6-$ keto- $\mathrm{PGF}_{1 \mathrm{~A}}$ were determined using GC/MS with minor modifications of a previously described method [24]. Briefly, cell culture supernatants were spiked with approximately $10 \mathrm{ng}$ of deuterated internal standards. The methoxime derivatives were obtained by treatment with O-methylhydroxylamine hydrochloride in sodium acetate buffer. After acidification $(\mathrm{pH}$ 2.6), analytes were extracted and further derivatized to the correspondent pentafluorobenzyl esters. Samples were purified by thin-layer chromatography, and two broad zones with $\mathrm{R}_{\mathrm{f}} 0.03$ to 0.39 and 0.4 to 0.8 were scraped off and eluted. After withdrawal of the organic solvent, trimethysilyl ethers were prepared by reaction with bis(trimethylsilyl)-trifluoroacetamide and thereafter injected into the $\mathrm{GC} /$ MS/MS. We used a Finnigan (Thermo Fisher Scientific GmbH, Dreieich, Germany) MAT TSQ700 GC/MS/MS, equipped with a Varian 3400 gas chromatograph (Varian, Inc., Palo Alto, CA, USA) and a CTC A200s autosampler (CTC Analytics AG, Zwingen, Switzerland). GC of prostanoid derivatives was carried out on a DB-1 (20 m, 0.25 
$\mathrm{mm}$ ID, $0.25-\mu \mathrm{m}$ film thickness) capillary column (Analyt $\mathrm{GmbH}$, Mühlheim, Germany) in the splitless injection mode. GC/MS/MS parameters were exactly as described by Schweer and colleagues [24].

\section{Real-time polymerase chain reaction}

Total RNA was extracted and purified from the cells following the 3D collagen gel contraction assay using Trizol (Invitrogen Corporation) and RNeasy Micro Kits (Qiagen $\mathrm{GmbH}$, Hilden, Germany). Reverse transcription was performed using $2 \mu \mathrm{g}$ of RNA, M-MuLV-reverse transcriptase, and hexamer primers (Peqlab Biotechnologie $\mathrm{GmbH}$, Erlangen, Germany). Real-time polymerase chain reactions (PCRs) were performed using validated QuantiTect ${ }^{\circledR}$ primers (Qiagen $\mathrm{GmbH})$ for $\alpha$-SMA (QT00088102), collagen type I (QT00037793), and 18S RNA (QT00199367), as well as the QuantiTect SYBR $^{\circledR}$ Green quantitative PCR Supermix (Invitrogen Corporation), an ABI 7300 device (Applied Biosystems Deutschland GmbH, Darmstadt, Germany), and the following thermal profile: 15 minutes at $95^{\circ} \mathrm{C}, 40$ cycles of 15 seconds at $94^{\circ} \mathrm{C}, 30$ seconds at $55^{\circ} \mathrm{C}$, and 35 seconds at $72^{\circ} \mathrm{C}$, followed by a dissociation step to confirm specificity of the reaction. The results were quantified using the $2^{\Delta \mathrm{Ct}}$ method and analyzed with the SDS 2.1 software (Applied Biosystems Deutschland $\mathrm{GmbH}$ ). Measurement values were indicated as fold expression of the housekeeping gene $18 S$.

\section{Western immunoblot}

MFs $\left(5 \times 10^{5}\right.$ cells/medium culture flask $)$ were cultured with or without the COX2 inhibitor diclofenac $(10 \mu \mathrm{g} / \mathrm{mL})$ in DMEM containing 1\% FCS. Protein extraction was performed using ice-cold lysis buffer $(2 \mathrm{M}$ Tris/ $\mathrm{HCl}, \mathrm{pH} 6.8$ to 7.5 containing SDS, glycerol, and brome phenol blue). For each sample, $10 \mu \mathrm{g}$ of protein was denatured, subjected to $10 \%$ SDS-polyacrylamide gel electrophoresis, and blotted to a polyvinylidene difluoride membrane (Millipore $\mathrm{GmbH}$, Schwalbach, Germany). The membranes were blocked in Tris/Tween 20 (TBST pH 7.4) containing $3 \%$ milk powder for 1 hour and incubated with primary mouse anti-human antibodies against $\alpha$-SMA (dilution 1:100, clone 1A4; Dako), COX2 (1:250, clone 33/COX2; BD Biosciences), and $\beta$-actin (dilution 1:10,000; Sigma-Aldrich Chemie $\mathrm{GmbH})$ overnight at $4^{\circ} \mathrm{C}$. Immunoreactive bands were detected with secondary horseradish peroxidase-conjugated anti-mouse antibodies (diluted 1:5,000; Cell Signaling Technology, Inc./New England Biolabs GmbH, Frankfurt am Main, Germany) and visualized by enhanced chemiluminescence detection reagents (Western Lightning Plus Kit; PerkinElmer Inc., Waltham, MA, USA) on autoradiograph films (Agfa Curix HT 1.000 G Plus; Agfa-Gevaert N.V., Mortsel, Belgium).

\section{Statistical analysis}

All experiments and measurements were performed at least in triplicate, and the number of measurements for each experiment is indicated in the figure legends. For statistical analysis, the SPSS 10.07 software (SPSS Inc., Chicago, IL, USA) was used. The data distribution was defined by medians \pm quartiles. For fold comparisons, the measurement values were normalized to the respective individual replicate samples of the control group and transformed to a $\log 2$ scale. The data distribution was presented in box plots. For multiple comparisons, the paired non-parametric Wilcoxon test was performed. Differences were considered to be statistically significant for $P<0.05$ and depicted by $* P<0.05$, $* * P<0.01$, and $* * * P<0.001$.

\section{Results}

Contracted elbow joint capsules reveal high numbers of $a-$ SMA-positive cells

The histological analysis of the biopsies from hip joint capsules yielded a comparable pattern for every patient studied. Beneath the synovial membrane consisting of a monolayer or a multilayer of synoviocytes as well as loose soft tissue with small blood vessels, a thin layer of fat tissue was observed. The layers underneath showed a regularly oriented fiber-rich ECM with low numbers of spindle-like cells that were negative for $\alpha$-SMA (Figure 2a). The smooth muscle cells of the blood vessels reacted strongly positive with antibodies against $\alpha$-SMA and thus were used as an internal positive control (Figure 2b). In contrast, the specimens of contracted elbow joint capsules were interspersed with small spindle-like cells that were strongly positive for $\alpha$-SMA by immunohistochemistry (Figure 2c, d). Each patient studied with contracted capsule revealed comparable $\alpha$-SMA staining pattern. The soft tissue layer showed a more irregular, partially sclerosing fibrous tissue, occasionally representing mucoid degeneration and lymphocytic infiltrates.

\section{Mature joint capsule fibroblasts in culture express a-SMA}

Only a few days after incubation, the typical spindle-like shape of in vitro cultured fibroblasts (Figure 3a) increasingly changed toward the phenotype of stellate cells (Figure $3 b$ ), which were strongly positive for the MF marker $\alpha$ SMA (Figure 3c, d). The positive staining for $\alpha$-SMA focused on regions of intracellular stress fibers, a hallmark of MFs. Before the start of the experiments, the preconfluent cell cultures contained almost $80 \%$ to $100 \% \alpha$-SMApositive cells (Figure 3d).

\section{The pro-inflammatory cytokine TNF- $a$ induces myofibroblast proliferation}

Upon addition of TNF- $\alpha$, MF cultures revealed a dosedependent increase of cell viability and proliferation (Figure 4). Compared with the control group, cell proliferation 


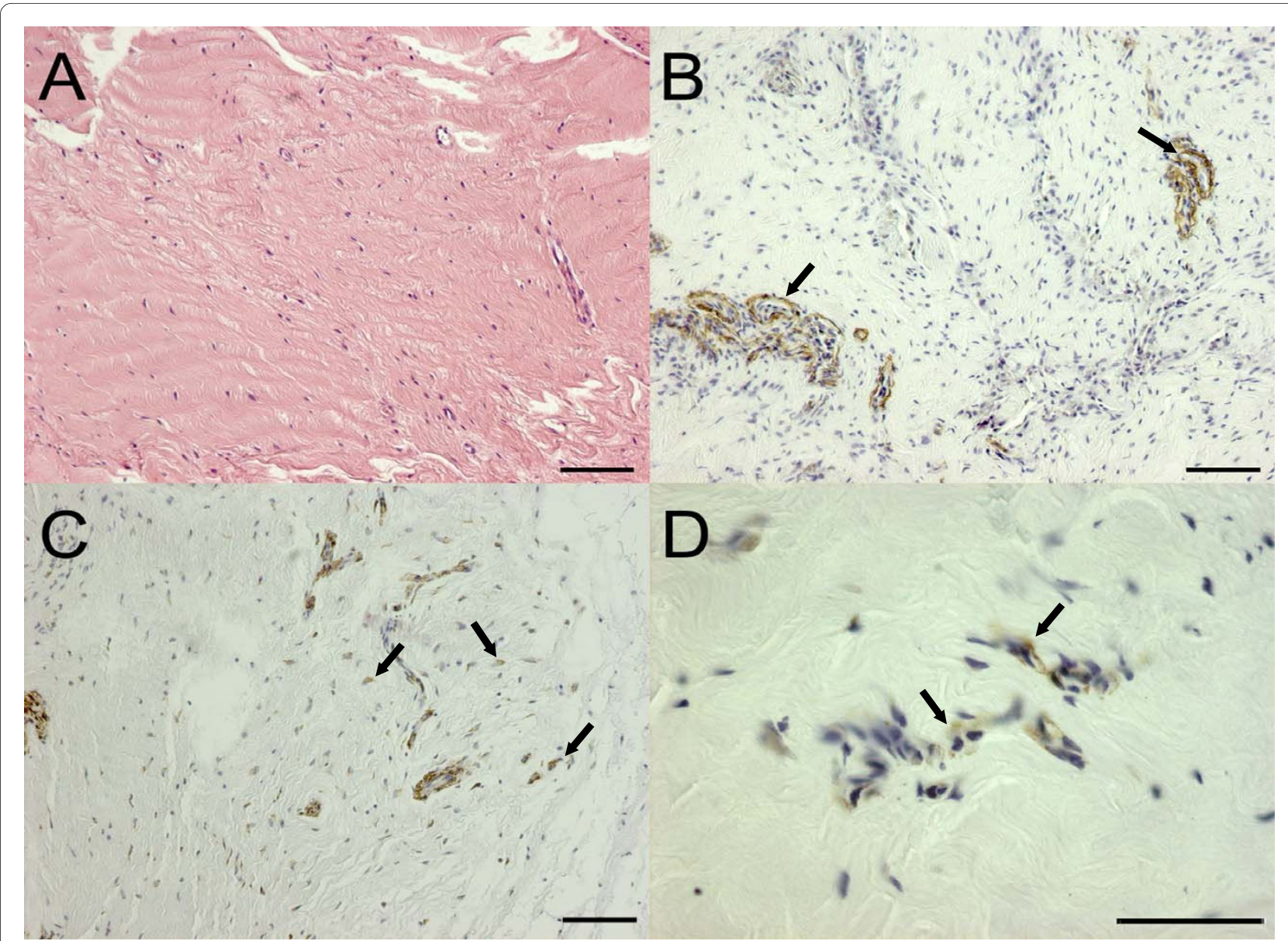

Figure 2 Expression of the myofibroblast marker alpha-smooth muscle actin (a-SMA) in hip joint and contracted elbow joint capsules. Biopsy sections were stained as indicated in Materials and methods. (a) Hematoxylin-eosin staining of hip joint capsules revealed parallel orientation of the collagen fibers and small spindle-like fibrocytes. (b) The immunohistochemical detection of a-SMA in hip joint capsules showed that only smooth muscle cells associated with blood vessels were positive for this marker (arrows). (c, d) Arrows indicate multiple positive cells in the immunohistochemical staining for a-SMA (brown dye) in contracted elbow joint capsule which were not linked to blood vessels. Scale bars $=100 \mu \mathrm{m}$.

was significantly induced by $1 \mathrm{ng} / \mathrm{mL} \mathrm{TNF}-\alpha$ and did not notably increase proliferation at the higher concentration of the cytokine (Figure 4 and Table 1). The proliferative effect of TNF- $\alpha$ (1 or $10 \mathrm{ng} / \mathrm{mL})$ was significantly reduced by its blocker IFX $(10 \mu \mathrm{g} / \mathrm{mL})$. MFs cultured with IFX only showed no significant differences in terms of cell viability compared with the control group (Figure 4 and Table 1). Interestingly, coincubation of MFs with TNF- $\alpha(10 \mathrm{ng} / \mathrm{mL})$ and the COX2 inhibitor diclofenac $(10 \mu \mathrm{g} / \mathrm{mL})$ resulted in a significant inhibition of TNF- $\alpha$-induced cell proliferation.

\section{TNF- $a$ inhibits contractile forces exhibited by myofibroblasts}

In comparison with the controls, the addition of $1 \mathrm{ng} / \mathrm{mL}$ TNF- $\alpha$ significantly inhibited collagen gel contraction as the gel surfaces of this group were significantly larger (Figure $5 \mathrm{a}, \mathrm{b}$ and Table 1). This effect is indicative of reduced contractile forces exhibited by MFs. The inhibition of colla- gen gel contracture was even stronger upon the application of $10 \mathrm{ng} / \mathrm{mL}$ TNF- $\alpha$. This inhibitory effect of the cytokine was significantly blocked by IFX as the surface areas of the collagen gels reversed to a dimension that was comparable to the controls. MFs cultured with IFX only showed no significant change of contraction behavior compared with the controls (Figure 5a, b and Table 1). The addition of diclofenac to collagen gels that were stimulated with $10 \mathrm{ng} /$ $\mathrm{mL}$ TNF- $\alpha$ before significantly reversed the TNF- $\alpha$ effect and promoted ECM contraction (Figure 5a, b and Table 1).

\section{TNF-a suppresses a-SMA and collagen type I gene expression in myofibroblasts}

Whereas the lower concentration of TNF- $\alpha$ revealed low inhibitory effects on gene expression of $\alpha-S M A$ and collagen type I, the expression of these two transcripts was significantly downregulated upon addition of $10 \mathrm{ng} / \mathrm{mL}$ TNF$\alpha$ (Figure $6 \mathrm{a}, \mathrm{b}$ and Table 1). This suppressive effect on 


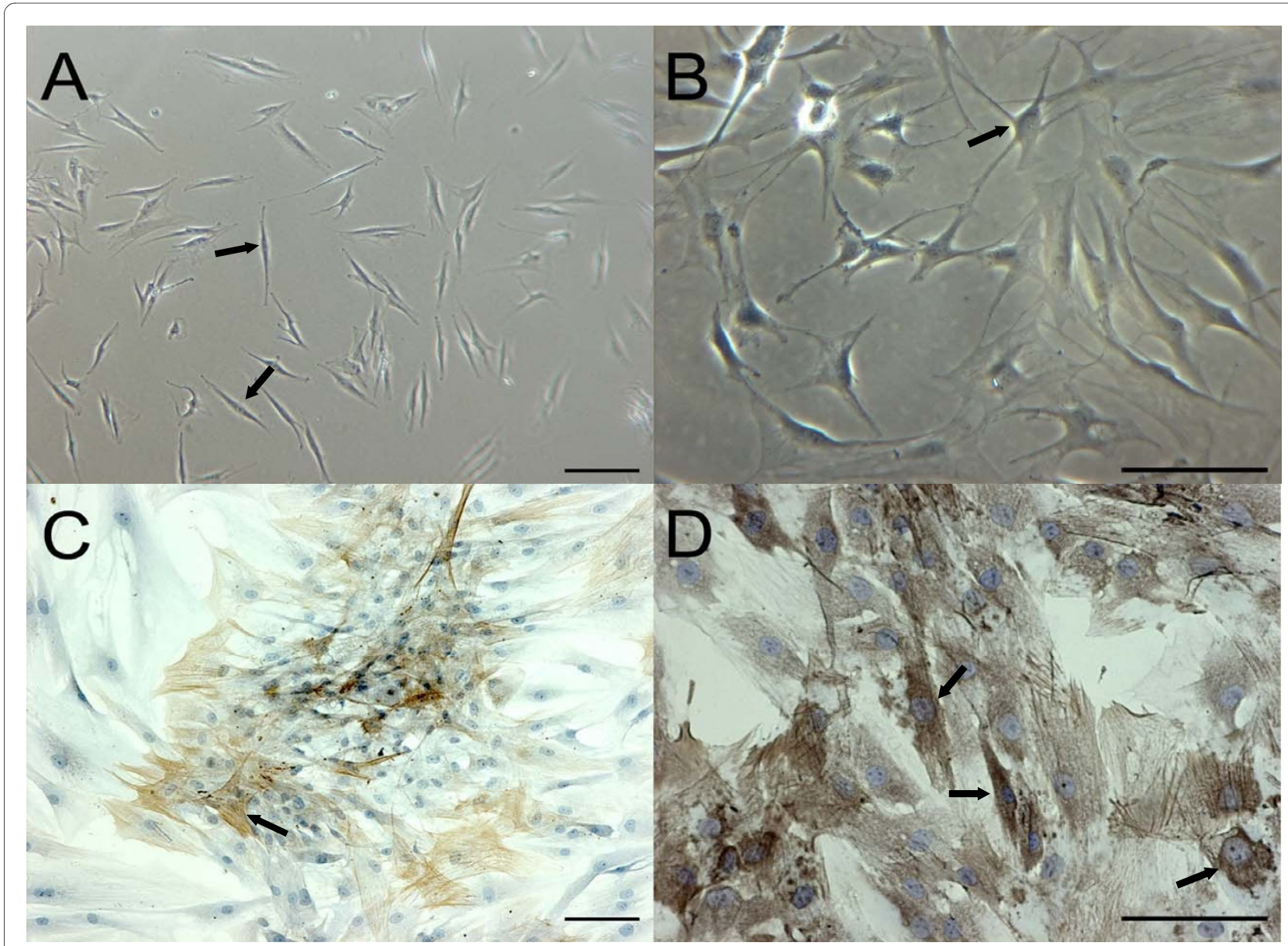

Figure 3 Phenotype of the cells used in this study. (a) Early cultures of fibroblasts were characterized by a typical spindle-like shape (arrows) and gradually matured into myofibroblasts (b) revealing typical stellate-shaped morphology (arrows) over the course of culture. (c, d) The myofibroblast cell marker alpha-smooth muscle actin was detected in confluent cell cultures as indicated in Materials and methods. Scale bars $=100 \mu \mathrm{m}$.

gene expression of these two markers was blocked by IFX, as the expression of both genes reverted almost to the level of the control group, and was significantly reduced by the COX2 inhibitor diclofenac. However, IFX alone did not influence the gene expression of $\alpha-S M A$ and collagen type $I$ (Figure 6a, b and Table 1).

\section{The effects of TNF- $a$ on myofibroblasts are mediated by prostaglandin E2 synthesis}

Using immunfluorescence staining and Western blot analysis, we found that $\alpha$-SMA-positive human MFs did express the enzyme COX2 (Figure 7a, b), which is required for the synthesis of $\mathrm{PGE}_{2}$. GC/MS analysis revealed a dramatic time-dependent increase of $\mathrm{PGE}_{2}$ concentrations in MF cultures upon stimulation with TNF- $\alpha$. Low and high concentrations of TNF- $\alpha$ yielded a comparable synthesis level of $\mathrm{PGE}_{2}$, with a peak response after 24 and 48 hours (Figure $7 c)$. Interestingly, the syntheses of both $\mathrm{PGF}_{1 \mathrm{~A}}$ and $\mathrm{PGF}_{2 \mathrm{~A}}$ (data not shown) were not affected by TNF- $\alpha$. The $\mathrm{PGE}_{2}$ levels in the control group were as low as in culture medium without cells, indicating that only low levels of $\mathrm{PGE}_{2}$ were synthesized during basal culture conditions. Coincubation of MFs with TNF- $\alpha$ (10 ng/mL) and diclofenac $(10 \mu \mathrm{g} / \mathrm{mL})$ resulted in a complete abrogation of the TNF- $\alpha$-mediated increase in $\mathrm{PGE}_{2}$ synthesis (Figure $7 \mathrm{c}$ ), which was associated with a significant decline in TNF- $\alpha$-induced effects on cell proliferation (Figure 4), ECM contraction (Figure $5 \mathrm{~b}$ ), and collagen type $I$ gene expression (Figure $6 \mathrm{~b}$ ). Although the TNF- $\alpha$-mediated inhibition of $\alpha-S M A$ gene expression was also attenuated by coincubation with diclofenac, the treatment with diclofenac did not reduce the overall effects of TNF- $\alpha$ on MF cell function to the same extent as IFX (Figure 6a, b). Furthermore, treatment of MFs with $10 \mu \mathrm{g} / \mathrm{mL}$ diclofenac only did not reveal any significant effects on the protein expression of COX2 or $\alpha$-SMA (Figure 7a, b). 


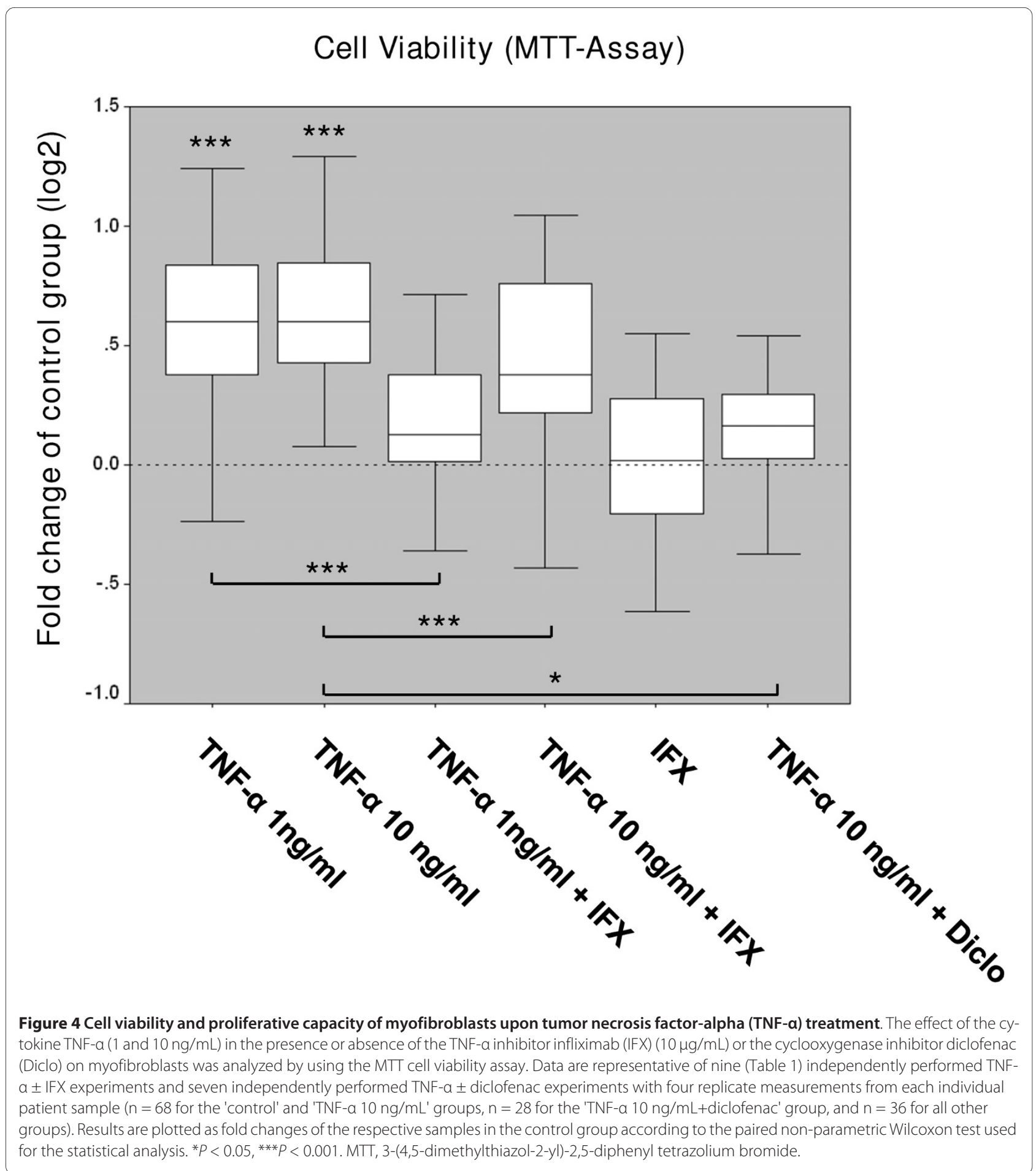

\section{Discussion}

Tissue healing is a complex process that requires activation, migration, and differentiation of various cells that are capable of ECM synthesis and later wound repair. Therefore, transformation of fibroblasts to contractile MFs is generally accepted to be a key element in early wound healing. In this study, we could show that in contrast to hip joint capsules of patients who did not suffer from any condition known to affect the ROM of the respective joints, the number of $\alpha$ SMA-positive MFs is notably increased in the biopsies of contracted joint capsules after injury. To therapeutically counteract an excessive ECM synthesis and contraction, it is most important to understand the molecular pathways that regulate the activation and function of MFs. 
Table 1: Data distribution and statistical analysis

\begin{tabular}{|c|c|c|c|c|c|c|}
\hline \multirow[b]{2}{*}{ Experiment } & \multirow[b]{2}{*}{ Group } & \multirow[b]{2}{*}{ Numbera } & \multicolumn{3}{|c|}{$\begin{array}{l}\text { Fold change of the respective patient sample in the } \\
\text { control group }(\log 2)\end{array}$} & \multirow[b]{2}{*}{ P value } \\
\hline & & & 25th quartile & Median & 75th quartile & \\
\hline \multirow[t]{6}{*}{ MTT assay } & $\begin{array}{l}\text { B: } 1 \mathrm{ng} / \mathrm{mL} \\
\text { TNF-a }\end{array}$ & 36 & 0.37 & 0.60 & 0.85 & B vs. A: $<0.001$ \\
\hline & $\begin{array}{l}\text { C: } 10 \mathrm{ng} / \mathrm{mL} \\
\text { TNF- } a\end{array}$ & 68 & 0.43 & 0.60 & 0.85 & C vs. A: $<0.001$ \\
\hline & $\begin{array}{l}\text { D: } \quad 1 \quad \mathrm{ng} / \mathrm{mL} \\
\text { TNF- } \mathrm{a}+10 \mu \mathrm{g} / \\
\mathrm{mL} \text { IFX }\end{array}$ & 36 & -0.03 & 0.13 & 0.39 & D vs. B: $<0.001$ \\
\hline & $\begin{array}{l}\mathrm{E}: 10 \mathrm{ng} / \mathrm{mL} \\
\text { TNF- } \mathrm{a}+10 \mu \mathrm{g} / \\
\mathrm{mL} \text { IFX }\end{array}$ & 36 & 0.21 & 0.38 & 0.78 & E vs. C: $<0.001$ \\
\hline & $\begin{array}{l}\mathrm{F}: 10 \mu \mathrm{g} / \mathrm{mL} \\
\text { IFX }\end{array}$ & 36 & -0.21 & 0.02 & 0.30 & F vs. A: 0.2 \\
\hline & $\begin{array}{l}\mathrm{G}: 10 \mathrm{ng} / \mathrm{mL} \\
\text { TNF- } \mathrm{a}+10 \mu \mathrm{g} / \\
\mathrm{mL} \text { Diclo }\end{array}$ & 28 & 0.02 & 0.16 & 0.30 & G vs. C: 0.031 \\
\hline \multirow[t]{6}{*}{$\begin{array}{l}\text { 3D collagen } \\
\text { gel }\end{array}$} & $\begin{array}{l}\text { B: } 11 n g / m L \\
\text { TNF- } a\end{array}$ & 40 & -0.01 & 0.23 & 0.46 & B vs. A: $<0.001$ \\
\hline & $\begin{array}{l}\text { C: } 10 \mathrm{ng} / \mathrm{mL} \\
\text { TNF-a }\end{array}$ & 52 & 0.71 & 0.90 & 1.47 & C vs. A: $<0.001$ \\
\hline & $\begin{array}{l}\text { D: } \quad 1 \quad \mathrm{ng} / \mathrm{mL} \\
\text { TNF- } \mathrm{a}+10 \mu \mathrm{g} / \\
\mathrm{mL} \text { IFX }\end{array}$ & 40 & -0.44 & -0.22 & 0.04 & D vs. B: $<0.001$ \\
\hline & $\begin{array}{l}\text { E: } 10 \mu \mathrm{ng} / \mathrm{mL} \\
\text { TNF- } a+10 \mu \mathrm{g} / \\
\mathrm{mL} \text { IFX }\end{array}$ & 40 & -0.35 & -0.14 & 0.19 & E vs. C: $<0.001$ \\
\hline & $\begin{array}{l}\text { F: } 10 \mu \mathrm{g} / \mathrm{mL} \\
\text { IFX }\end{array}$ & 40 & -0.23 & -0.01 & 0.15 & F vs. A: 0.6 \\
\hline & $\begin{array}{l}\mathrm{G}: 10 \mathrm{ng} / \mathrm{mL} \\
\text { TNF-a }+10 \mu \mathrm{g} / \\
\mathrm{mL} \text { Diclo }\end{array}$ & 40 & 0.04 & 0.17 & 0.67 & G vs. C: 0.002 \\
\hline
\end{tabular}

qPCR

\begin{tabular}{|c|c|c|c|c|c|c|}
\hline \multirow[t]{4}{*}{$a-S M A$} & $\begin{array}{l}\text { B: } 11 n g / m L \\
\text { TNF-a }\end{array}$ & 8 & -1.01 & -0.14 & 1.15 & B vs. A: 0.8 \\
\hline & $\begin{array}{l}\text { C: } 10 \mathrm{ng} / \mathrm{mL} \\
\text { TNF-a }\end{array}$ & 25 & -6.29 & -5.64 & -3.48 & C vs. A: $<0.001$ \\
\hline & $\begin{array}{l}\text { D: } \quad 1 \quad \mathrm{ng} / \mathrm{mL} \\
\text { TNF- } a+10 \mu \mathrm{g} / \\
\mathrm{mL} \text { IFX }\end{array}$ & 8 & -1.20 & -0.004 & 0.90 & D vs. B: 0.4 \\
\hline & $\begin{array}{l}\text { E: } 10 \mathrm{ng} / \mathrm{mL} \\
\text { TNF- } \mathrm{a}+10 \mu \mathrm{g} / \\
\mathrm{mL} \text { IFX }\end{array}$ & 8 & -0.63 & -0.50 & 0.10 & E vs. C: 0.01 \\
\hline
\end{tabular}


Table 1: Data distribution and statistical analysis (Continued)

\begin{tabular}{|c|c|c|c|c|c|c|}
\hline & $\begin{array}{l}\text { F: } 10 \mu \mathrm{g} / \mathrm{mL} \\
\text { IFX }\end{array}$ & 8 & -0.45 & -0.32 & -0.12 & F vs. A: 0.5 \\
\hline & $\begin{array}{l}\mathrm{G}: 10 \mathrm{ng} / \mathrm{mL} \\
\text { TNF- } \mathrm{a}+10 \mu \mathrm{g} / \\
\mathrm{mL} \text { Diclo }\end{array}$ & 9 & -4.85 & -4.32 & -3.74 & G vs. C: 0.015 \\
\hline \multirow[t]{6}{*}{ Collagen type I } & $\begin{array}{l}\text { B: } 11 \mathrm{ng} / \mathrm{mL} \\
\text { TNF-a }\end{array}$ & 8 & -0.36 & -0.007 & 0.59 & B vs. A: 1.0 \\
\hline & $\begin{array}{l}\text { C: } 10 \mathrm{ng} / \mathrm{mL} \\
\text { TNF- } a\end{array}$ & 17 & -4.35 & -3.47 & -3.00 & C vs. A: 0.01 \\
\hline & $\begin{array}{l}\text { D: } 1 \quad \mathrm{ng} / \mathrm{mL} \\
\text { TNF- } \mathrm{a}+10 \mu \mathrm{g} / \\
\mathrm{mL} \text { IFX }\end{array}$ & 8 & -0.93 & -0.30 & 0.54 & D vs. B: 0.2 \\
\hline & $\begin{array}{l}\text { E: } 10 \mathrm{ng} / \mathrm{mL} \\
\text { TNF- } \mathrm{a}+10 \mu \mathrm{g} / \\
\mathrm{mL} \text { IFX }\end{array}$ & 8 & -1.03 & -0.20 & 0.50 & Evs. C: 0.01 \\
\hline & $\begin{array}{l}\text { F: } 10 \mu \mathrm{g} / \mathrm{mL} \\
\text { IFX }\end{array}$ & 8 & -1.60 & -0.009 & 0.27 & F vs. A: 0.6 \\
\hline & $\begin{array}{l}\mathrm{G}: 10 \mathrm{ng} / \mathrm{mL} \\
\text { TNF- } \mathrm{a}+10 \mu \mathrm{g} / \\
\mathrm{mL} \text { Diclo }\end{array}$ & 9 & -2.21 & -1.84 & -0.93 & G vs. C: 0.015 \\
\hline
\end{tabular}

aNumber of measurements. 3D, three-dimensional; a-SMA, alpha-smooth muscle actin; Diclo, Diclofenac; IFX, infliximab; MTT, 3-(4,5-dimeth-

ylthiazol-2-yl)-2,5-diphenyl tetrazolium bromide; qPCR, quantitative polymerase chain reaction; TNF-a, tumor necrosis factor-alpha.

Over the years, it has become evident that MFs arise from a variety of sources and may develop different phenotypes according to the involved organ and the physiological or pathological situation $[9,18,25,26]$. With respect to the current literature, the origin of the cells as well as their cytokine environment [9] are decisive for understanding $\mathrm{MF}$ development and regulation. Although TNF- $\alpha$ was shown to mediate different target cells in the pathogenesis of fibrocontractive disorders, the role of this cytokine in the pathogenesis of post-traumatic joint contracture has not been defined yet.

Here, we describe in detail the functional effect of TNF- $\alpha$ on human MFs that differentiated from fibroblasts isolated from hip joint capsules. Although it has been previously described that normal elbow capsules can be obtained from organ donors [7] for limited resources, we did not take capsules of organ donors as a source of MFs for our functional experiments. We could demonstrate that TNF- $\alpha$ is capable of inducing cell viability and proliferation in MF cultures. This effect was already present at a low concentration of the cytokine. However, the stimulation of the cells with higher concentrations of TNF- $\alpha$ did not result in additional increase of the cell proliferation rate, presumably due to complete receptor saturation. Furthermore, as the proliferative effect of TNF- $\alpha$ was significantly reduced by its inhibi- tor IFX, we conclude that cell proliferation was specifically mediated by this cytokine. On the other hand, we did not observe any significant effects of IFX without TNF- $\alpha$ on cell viability and proliferation in MF cultures. Although our results are consistent with previous findings that TNF- $\alpha$ has the potential to induce proliferation of fibroblasts and MFs $[27,28]$, there is also significant evidence of the antiproliferative effect of TNF- $\alpha$ as previously described in liver MFs, the hepatic stellate cells (HSCs) [29]. Such differences in regulation processes emphasize once more the concept of tissue-specific regulation of MF function.

Despite this positive stimulatory effect on cell proliferation, we found that the contractile forces of MFs were significantly inhibited upon application of TNF- $\alpha$ according to a significant inhibition of $\alpha-S M A$ gene expression. This fact supports the hypothesis that the fibroblast-to-MF transition may be affected by TNF- $\alpha$. Studies in the past revealed that the contractile function of the MFs is linked to the expression of $\alpha$-SMA and different ECM proteins like collagen type I. According to a previous study on rat lung fibroblasts [30], we found that the functional inhibition of ECM contraction by human joint capsule MFs upon TNF- $\alpha$ treatment was clearly associated with a significant downregulation of $\alpha-S M A$ and collagen type I gene expression. Interestingly, whereas the lower concentration of TNF- $\alpha$ induced prolifer- 
(a)

day 6

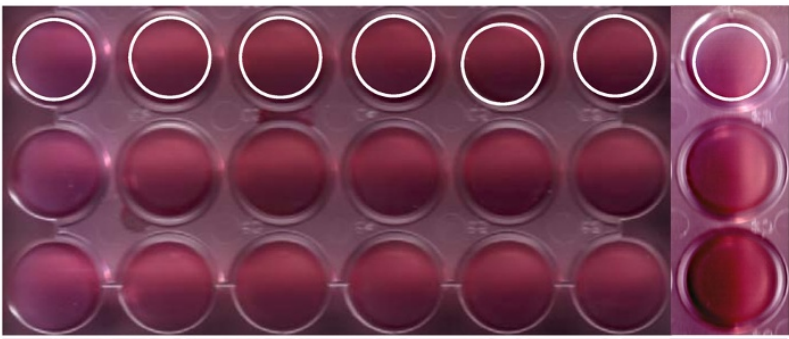

day 8

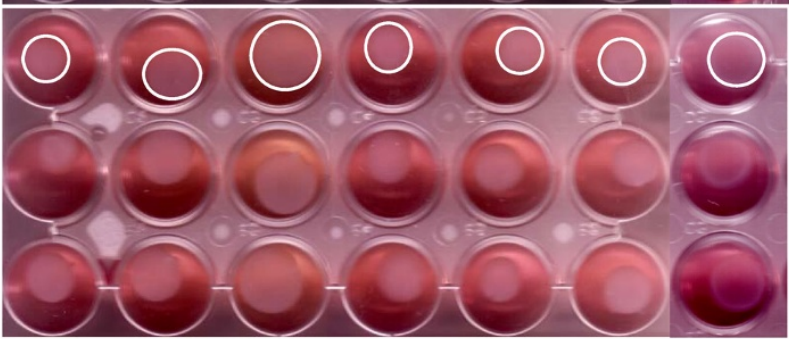

(b)
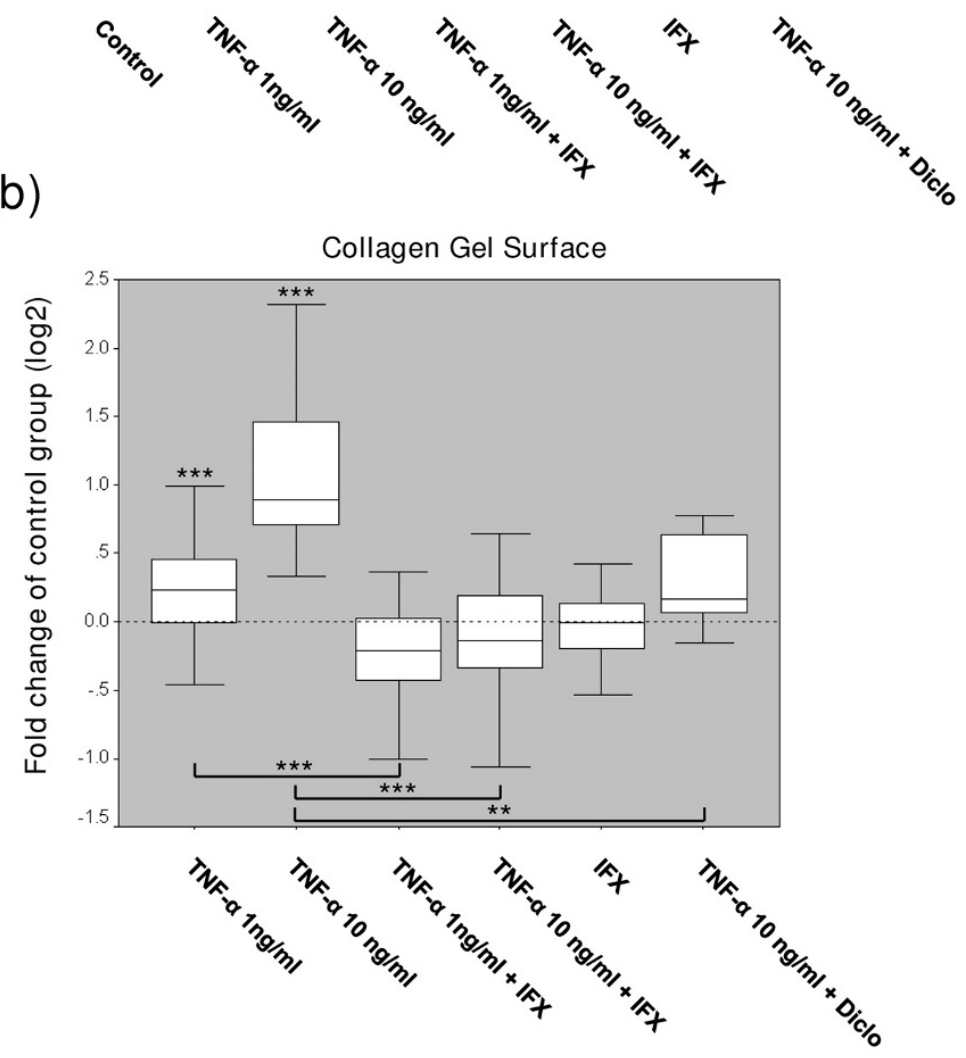

Figure 5 The effect of tumor necrosis factor-alpha (TNF-a) on collagen gel contraction. (a) Images of the three-dimensional collagen gel contraction assay shown are representative of all (Table 1) independently performed experiments. Three collagen gels of each group are shown before (day 6) and after (day 8) releasing the gels from the culture plates, revealing distinct differences in gel contraction in the groups upon TNF-a and infliximab (IFX) or diclofenac (Diclo) coincubation. White circles in the first rows of the plates illustrate the margins of the gels comprising the gel surface areas. (b) Gel surfaces of the floating gels in the presence or absence of TNF-a (1 and $10 \mathrm{ng} / \mathrm{mL}$ ), the TNF-a inhibitor IFX (10 $\mu \mathrm{g} / \mathrm{mL})$, or diclofenac (10 $\mu \mathrm{g} / \mathrm{mL}$ ) were scanned and calculated as described in Materials and methods. Data are representative of 10 (Table 1) independently performed TNF- $a$ \pm IFX experiments and three independently performed TNF- $a \pm$ diclofenac experiments with four replicate measurements from each individual patient sample ( $\mathrm{n}=52$ for the 'control' and 'TNF-a $10 \mathrm{ng} / \mathrm{mL}$ ' groups, $\mathrm{n}=12$ for the 'TNF-a $10 \mathrm{ng} / \mathrm{mL}+$ diclofenac' group, and $\mathrm{n}=40$ for all other groups). Results are plotted as fold changes of the respective samples in the control group according to the paired non-parametric Wilcoxon test used for the statistical analysis. ${ }^{* *} P<0.01,{ }^{* * *} P<0.001$. 
(a)

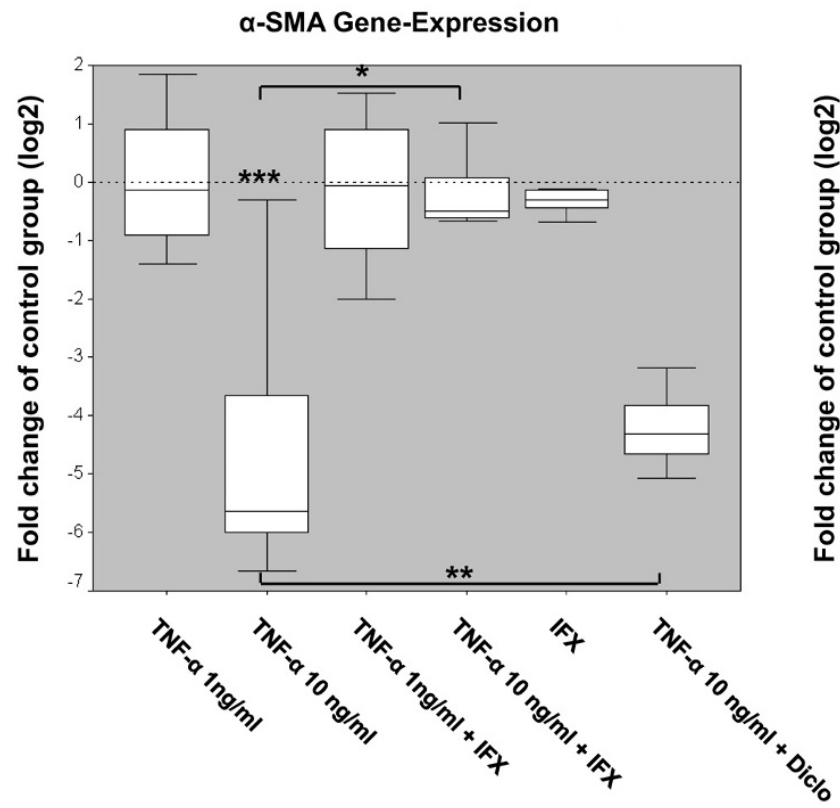

(b)

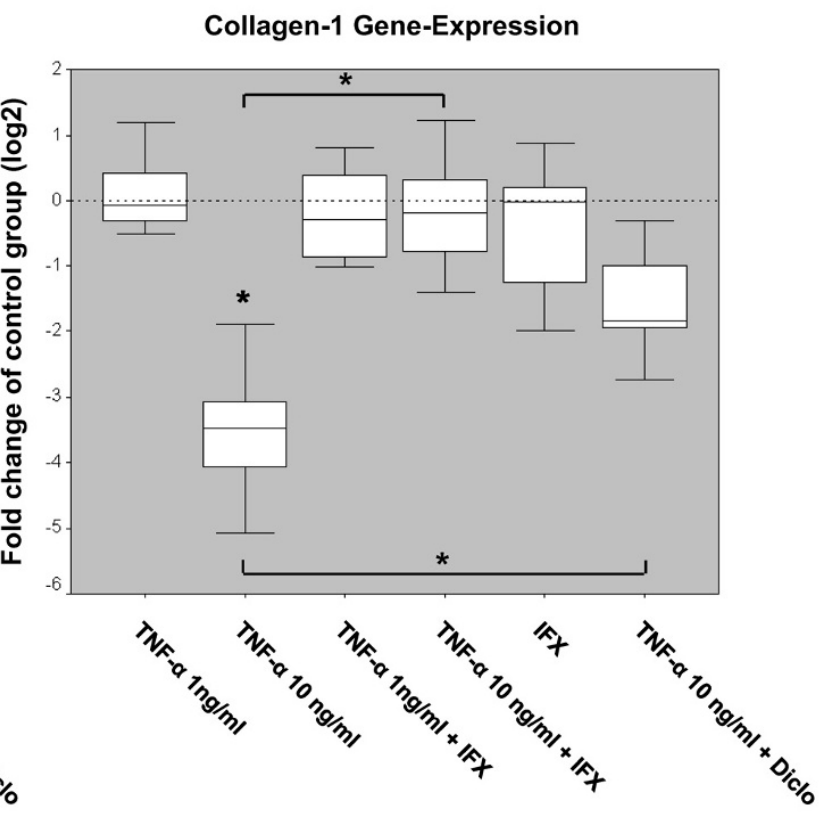

Figure 6 Tumor necrosis factor-alpha (TNF-a) downregulates gene expression of the myofibroblast marker alpha-smooth muscle actin (aSMA) and the extracellular matrix protein collagen typel. The mRNA expression of $a-S M A$ (a) and collagen type / (b) was determined for every group (Figure 1) by quantitative real-time polymerase chain reaction. The mRNA level of $a$-SMA of every group examined was normalized to the housekeeping gene 18S. Data are representative of four (Table 1) independently performed TNF- $a \pm$ infliximab (IFX) experiments and TNF- $a \pm$ diclofenac (Diclo) experiments with duplicate measurements from each individual patient sample ( $\mathrm{n}=16$ for the 'control' and 'TNF- $a 10 \mathrm{ng} / \mathrm{mL}$ ' groups and $n=8$ for all other groups). Results are plotted as fold changes of the respective samples in the control group according to the paired non-parametric Wilcoxon test used for the statistical analysis. ${ }^{*} P<0.05,{ }^{* *} P<0.01,{ }^{* * *} P<0.001$.

ation and significant inhibition of contractile forces in MFs in the collagen gels, we did not find a significant inhibition of $\alpha$-SMA and collagen I gene expression at the lower level of this cytokine. Previous studies provided evidence that the decrease in collagen synthesis occurred without a change in cell number [20], indicating that the inhibition of the ECM contraction might be due to decreased synthesis at the cellular level. The synthesis of collagen is a hallmark of the strict regulation of MFs by a complex cytokine environment. Different studies revealed that the pro-inflammatory cytokines TNF- $\alpha$ and IL- $1 \beta$ have profound effects on collagen metabolism in fibroblasts in vitro by downregulating the synthesis of collagen [18,20,31]. Singer and Clark [32] demonstrated that TNF- $\alpha$ was able to modulate ECM turnover by inhibition of protein synthesis and activation of matrix metalloproteinases. Moreover, there is evidence that TNF- $\alpha$ is capable of antagonizing TGF- $\beta 1$-induced upregulation of type I and III collagen expression in mouse fibroblasts [33]. Thus, the antagonistic relationship between TGF- $\beta 1$ and TNF- $\alpha$ may play an important role in maintaining tissue homeostasis and ECM deposition, whereas the cytokine network that modulates this process is presumably more complex. Based on these data, we believe that the inhibition of ECM contraction by TNF- $\alpha$ might be due to a functional inhibition of human MFs both by a reduced expression level of $\alpha-S M A$ as well as by the decrease of ECM protein expression.

The antiproliferative impact of TNF- $\alpha$ in human HSCs, the MFs of the liver, was previously described to be mediated by increased formation of nuclear factor-kappa-B (NF$\kappa B)$ DNA-binding complexes [29]. Interestingly, the promoter region of the $C O X 2$ gene possesses specific binding sites for the NF- $\mathrm{kB}$ complexes. Thus, treatment of HSCs with TNF- $\alpha$ was shown to positively regulate gene expression of $C O X 2$ and this accounted for basal COX activity in these cells [29]. On the other hand, exogenous treatment of fetal and adult lung fibroblast with $\mathrm{PGE}_{2}$ was reported to inhibit TGF- $\beta 1$-induced expression of $\alpha$-SMA and collagen type I by increasing cAMP production [34]. Based on these findings, we hypothesized that the effects of TNF- $\alpha$ on human joint capsule MFs may be mediated even by endogenous prostaglandin synthesis. Here, we could clearly show that human joint capsule MFs express COX2 under in vitro conditions (Figure 7a, b) and significantly upregulate synthesis of $\mathrm{PGE}_{2}$ (Figure 7c), but not $\mathrm{PGF}_{1 \mathrm{~A}}$ and $\mathrm{PGF}_{2 \mathrm{~A}}$, upon TNF- $\alpha$ treatment. The TNF- $\alpha$-mediated increase of $\mathrm{PGE}_{2}$ levels was completely blocked by the non-specific COX inhibitor diclofenac administered in a concentration that is 


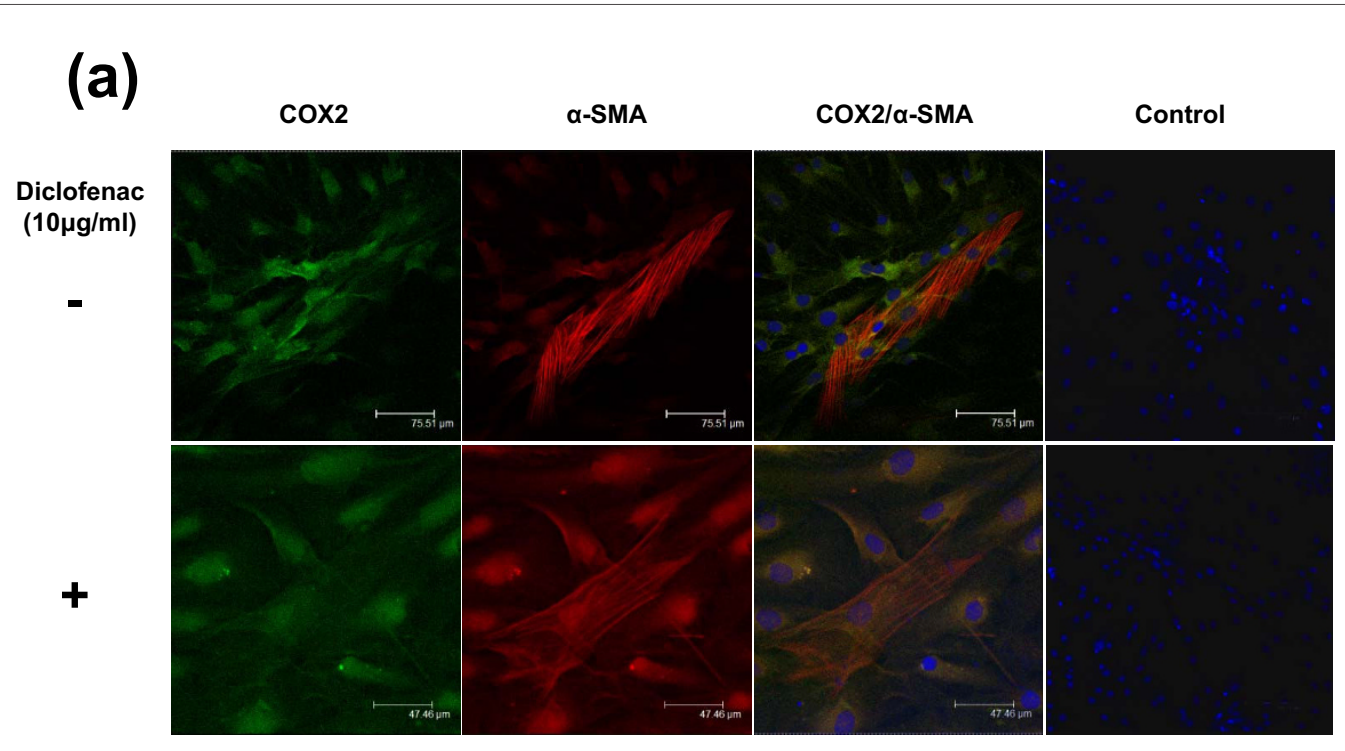

(b)

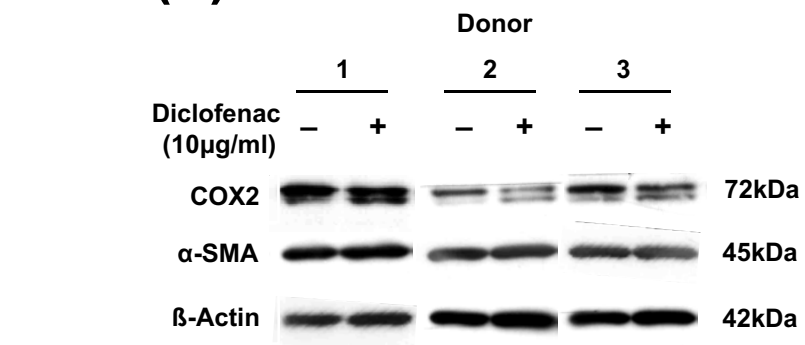

(c)

PGE2

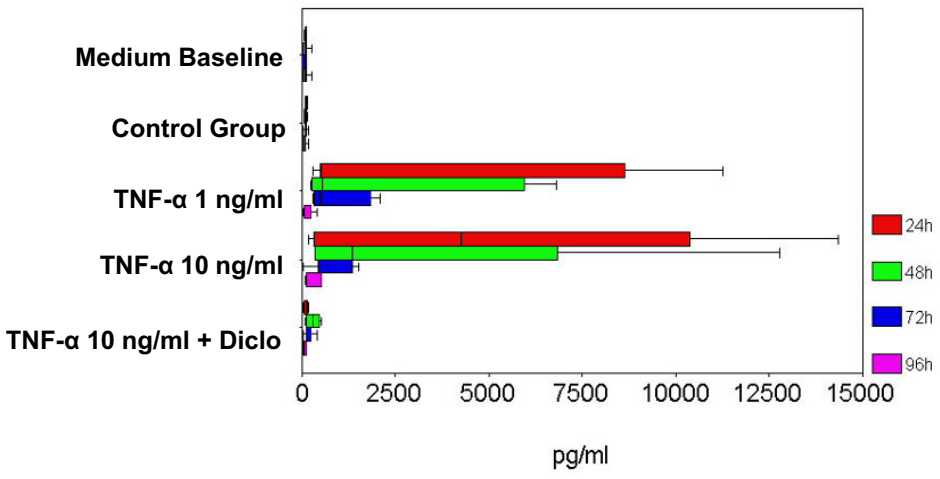

Figure 7 Tumor necrosis factor-alpha (TNF- $\alpha$ ) modulates the synthesis of prostaglandin $E_{2}\left(P G E_{2}\right)$ in alpha-smooth muscle actin ( $\alpha$-SMA)positive myofibroblasts (MFs). (a) Immunofluorescent staining of cyclooxygenase-2 (COX2) (first panel, green, fluorescein isothiocyanate filter) and a-SMA (second panel, red, Texas Red filter) in MF cultures with or without the COX2 inhibitor diclofenac (Diclo). The third panel illustrates merged images of Höchst 33248-stained nuclei (blue, DAPI filter) as well as immunofluorescence for COX2 and a-SMA. a-SMA-positive MFs derived from hip joint capsules express the enzyme COX2. The fourth panel shows merged images of the negative controls. Scale bars are shown in the lower right corner of each panel. (b) MFs of three different donors were exposed to $10 \mu \mathrm{g} / \mathrm{mL}$ diclofenac. The expression of a-SMA (45 kDa), COX2 (72 kDa), and $\beta$-actin ( $42 \mathrm{kDa}$ ) as a loading control was evaluated by using Western blots. A characteristic double band for the COX2 protein corresponding to the expected molecular weight represents different glycosylated forms of the enzyme. (c) Gas chromatographic/mass spectrometric analysis revealed a time-dependent increase of $\mathrm{PGE}_{2}$ concentration in MF cultures upon TNF-a stimulation with a peak after 24 and 48 hours. This effect was completely blocked by diclofenac. DAPI, 4'-6-diamidino-2-phenylindole. 


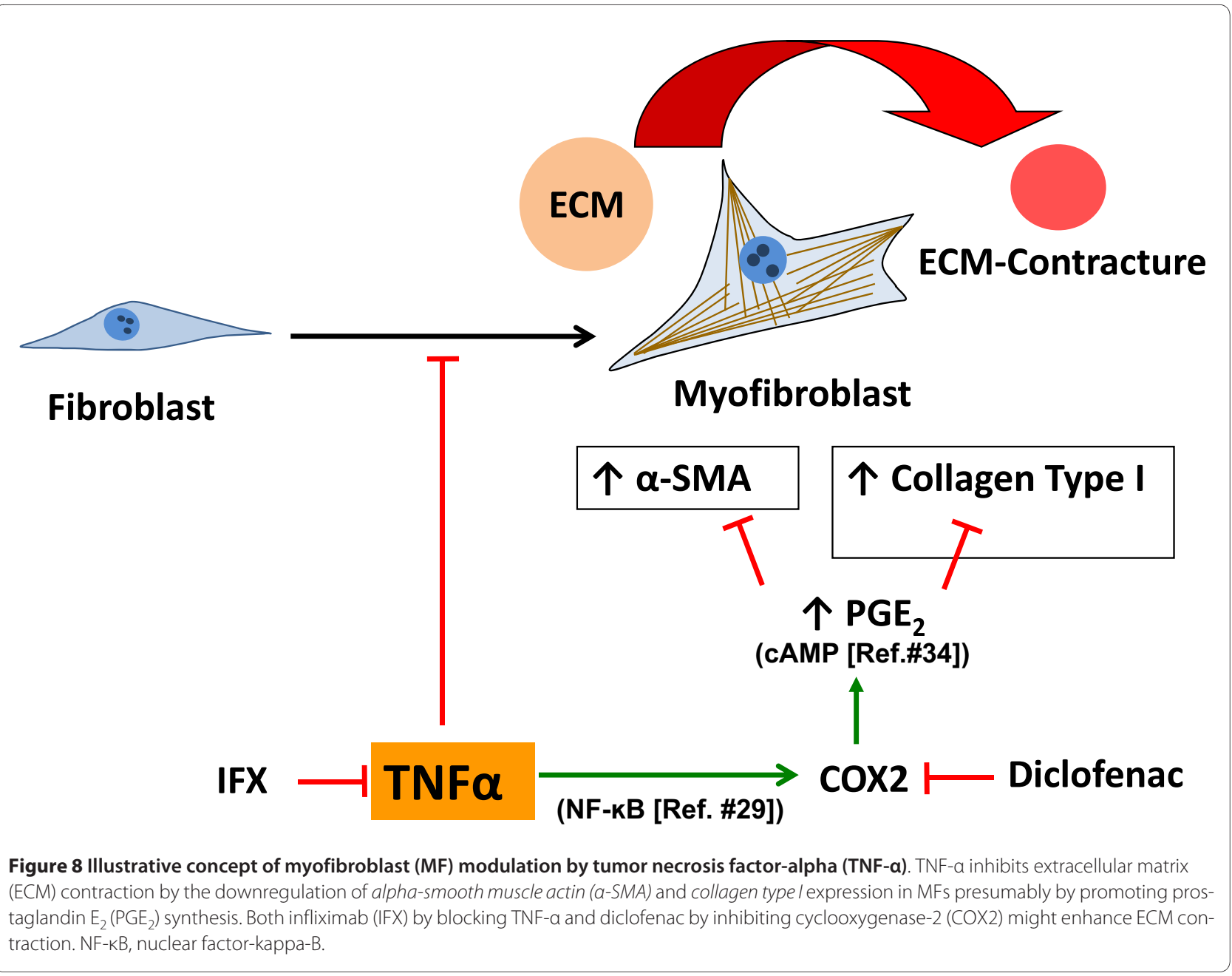

comparable to therapeutic but not toxic levels in humans [35]. Although some functional parameters of MFs were nearly completely restored by coincubation of TNF- $\alpha-$ treated cells with diclofenac (Figure 7c), the gene expressions of $\alpha-S M A$ and collagen type I (Figure $6 \mathrm{a}, \mathrm{b}$ ) were still significantly inhibited, suggesting that the effect of TNF- $\alpha$ could not be blocked at this concentration to the same extent as by the neutralizing antibody IFX.

\section{Conclusions}

In the present work, TNF- $\alpha$ modified the function of human MFs, suggesting a regulative effect of TNF- $\alpha$ during the wound healing. Whereas TNF- $\alpha$ had a high proliferative effect on MFs at low concentrations already, it functionally inhibited the contraction of the ECM and downregulated the gene expression of $\alpha-S M A$ and collagen type I. As these two genes were only significantly inhibited upon high concentrations of TNF- $\alpha$ stimulation compared with the control group, we conclude that TNF- $\alpha$ might have a dual, dosedependent modulatory effect on MFs at the beginning of a healing process. The effects of TNF- $\alpha$ on human joint cap- sule MFs (positive for the marker COX2) were associated with a significant increase of $\mathrm{PGE}_{2}$ synthesis, suggesting its crucial role in the regulation of this cell type. Accordingly, they were almost completely prevented by the inhibition of COX2 with diclofenac at a clinically relevant concentration. Our current concept of MF modulation is summarized and illustrated in Figure 8. Further evaluation is required in order to address the hypothesis that cell proliferation and MF function may be altered in clinical use by therapeutically applied immunomodulatory treatments. This established culture and 3D model potentially provide a basis for further investigations to shed new light on this complex cytokine network and to develop alternative non-operative treatment strategies of fibroconnective pathologies like post-traumatic contracture. Prophylactic pharmacological intervention could provide new specific treatment options for post-traumatic contractures and other fibroconnective pathologies.

\section{Abbreviations}

3D: three-dimensional; a-SMA: alpha-smooth muscle actin; BSA: bovine serum albumin; COX2: cyclooxygenase-2; DAB: 3,3'-diaminobenzidine; DMEM: Dul- 
becco's modified Eagle's medium; ECM: extracellular matrix; FCS: fetal calf serum; GC/MS/MS: gas chromatography/mass spectrometry/mass spectrometry; HSC: hepatic stellate cell; IFX: infliximab; MF: myofibroblast; MTT: 3-(4,5dimethylthiazol-2-yl)-2,5-diphenyl tetrazolium bromide; NF-kB: nuclear factorkappa-B; PBS: phosphate-buffered saline; PCR: polymerase chain reaction; PFA: 3.7\% paraformaldehyde; $\mathrm{PGE}_{2}$ : prostaglandin $\mathrm{E}_{2}$; PGF: prostaglandin $\mathrm{F} ; \mathrm{ROM}$ : range of motion; TGF- $\beta 1$ : transforming growth factor-beta 1; TNF-a: tumor necrosis factor-alpha.

\section{Competing interests}

The authors declare that they have no competing interests.

\section{Authors' contributions}

SGM helped to design the study and to prepare the final manuscript, carried out all of the experiments with myofibroblasts, and is the project leader. AH helped to design the study and to prepare the final manuscript, contributed to the establishment of the MTT assay and the 3D collagen gel model, and helped to perform the statistical analysis and the interpretation of the results. JW contributed to the establishment of the MTT assay and the 3D collagen gel model and helped to perform the statistical analysis and the interpretation of the results, to generate the hypothesis regarding the role of COX2 and PGE synthesis, and to perform the respective experiments. SK assisted in cell isolation and cell culture and helped to perform the MTT assays. UR participated in the design of the study, carried out the real-time PCR experiments, and assisted in performing the immunofluorescence analysis. $C B$ carried out the immunohistochemistry, participated in writing the manuscript, and helped to generate the hypothesis regarding the role of $\mathrm{COX} 2$ and $\mathrm{PGE}_{2}$ synthesis and to perform the respective experiments. BW helped to generate the hypothesis regarding the role of COX2 and $\mathrm{PGE}_{2}$ synthesis and to perform the respective experiments. HS-K provided a vial of infliximab and participated in writing the manuscript. LPM participated in writing the manuscript and helped to coordinate the study and to collect capsule biopsies during the surgeries. PMR participated in writing the manuscript, helped to coordinate the study and to collect capsule biopsies during the surgeries, and is the principal investigator. All authors read and approved the final manuscript.

\section{Acknowledgements}

We would like to acknowledge the substantial contribution of Angelika Ackermann in the establishment of all of the methods used in this study and her invaluable assistance in cell culture, in the immunofluorescence stainings, and in performing the Western immunoblots. We would like to thank Achim Tresch for the final review and verification of the statistical analysis. We are grateful to the patients of our clinic for their willingness to participate in our study. We would like to thank all trauma and orthopedic surgeons of our center for trauma and orthopedic surgery for their kind assistance in collecting joint capsules during surgeries. This work, including the article-processing charge, was supported in part by a research grant from Centocor B.V., Medical Affairs Europe (Leiden, The Netherlands) (NCR 2006-09284 EU-0155) and the University of Mainz. The authors declare that the study design, the collection and the interpretation of the data, and the presentation of information were not influenced by the mentioned organizations or by other people.

\section{Author Details}

'Department of Trauma and Orthopaedic Surgery, Johannes Gutenberg University School of Medicine, Langenbeckstr. 1, 55101 Mainz, Germany, 2Institute of Pathology, Johannes Gutenberg University School of Medicine, Langenbeckstr. 1, 55101 Mainz, Germany,

${ }^{3}$ Division of Rheumatology, Medizinische Poliklinik, Ludwig Maximilians University, Pettenkoferstr. 8a, 80336 Munich, Germany and 4 Eicosanoid and Mass Spectrometry Laboratory, Mother-Child Medical Center, Baldingerstrasse, 35043 Marburg, Germany

Received: 16 May 2009 Revisions Requested: 18 June 2009 Revised: 17 November 2009 Accepted: 8 January 2010 Published: 8 January 2010

\section{References}

1. Cooney WP III: Contractures of the elbow. In The Elbow and Its Disorders Edited by: Morrey BF. Philadelphia, PA: WB Saunders; 1993:464-475.
2. Bunker TD: Frozen shoulder: unravelling the enigma. Ann R Coll Surg Engl 1997, 79:210-213.

3. Hinz B: Formation and function of the myofibroblast during tissue repair. J Invest Dermatol 2007, 127:526-537.

4. Gabbiani G, Ryan GB, Majne G: Presence of modified fibroblasts in granulation tissue and their possible role in wound contraction. Experientia 1971, 27:549-550.

5. Serini G, Gabbiani G: Mechanisms of myofibroblast activity and phenotypic modulation. Exp Cell Res 1999, 250:273-283.

6. Tomasek JJ, Gabbiani G, Hinz B, Chaponnier C, Brown RA: Myofibroblasts and mechano-regulation of connective tissue remodelling. Nat Rev Mol Cell Biol 2002, 3:349-363.

7. Hildebrand KA, Zhang M, Hart DA: Myofibroblast upregulators are elevated in joint capsules in posttraumatic contractures. Clin Orthop Relat Res 2007, 456:85-91.

8. Desmouliere A, Chaponnier C, Gabbiani G: Tissue repair, contraction, and the myofibroblast. Wound Repair Regen 2005, 13:7-12.

9. Hinz B, Phan SH, Thannickal VJ, Galli A, Bochaton-Piallat ML, Gabbiani G: The myofibroblast: one function, multiple origins. Am J Pathol 2007, 170:1807-1816

10. Gabbiani G: The myofibroblast in wound healing and fibrocontractive diseases. J Pathol 2003, 200:500-503.

11. Hinz B, Mastrangelo D, Iselin CE, Chaponnier C, Gabbiani G: Mechanical tension controls granulation tissue contractile activity and myofibroblast differentiation. Am J Pathol 2001, 159:1009-1020.

12. Berndt A, Kosmehl H, Katenkamp D, Tauchmann V: Appearance of the myofibroblastic phenotype in Dupuytren's disease is associated with a fibronectin, laminin, collagen type IV and tenascin extracellular matrix. Pathobiology 1994, 62:55-58.

13. Tomasek J, Rayan GM: Correlation of alpha-smooth muscle actin expression and contraction in Dupuytren's disease fibroblasts. $J$ Hand Surg Am 1995, 20:450-455.

14. Ettema AM, Amadio PC, Zhao C, Wold LE, An KN: A histological and immunohistochemical study of the subsynovial connective tissue in idiopathic carpal tunnel syndrome. J Bone Joint Surg Am 2004, 86A:1458-1466.

15. Bunker TD, Reilly J, Baird KS, Hamblen DL: Expression of growth factors, cytokines and matrix metalloproteinases in frozen shoulder. J Bone Joint Surg Br 2000, 82:768-773.

16. Mauviel A, Qiu CY, Dong W, Evans CH, Uitto J: Transcriptional interactions of transforming growth-factor-beta with proinflammatory cytokines. Curr Biol 1993, 3:822-831.

17. Abraham DJ, Shiwen X, Black CM, Sa S, Xu Y, Leask A: Tumor necrosis factor alpha suppresses the induction of connective tissue growth factor by transforming growth factor-beta in normal and scleroderma fibroblasts. J Biol Chem 2000, 275:15220-15225.

18. Goldberg MT, Han YP, Yan C, Shaw MC, Garner WL: TNF-alpha suppresses alpha-smooth muscle actin expression in human dermal fibroblasts: an implication for abnormal wound healing. J Invest Dermatol 2007, 127:2645-2655.

19. Sullivan DE, Ferris M, Pociask D, Brody AR: Tumor necrosis factor-alpha induces transforming growth factor-beta1 expression in lung fibroblasts through the extracellular signal-regulated kinase pathway. Am J Respir Cell Mol Biol 2005, 32:342-349.

20. Siwik DA, Chang DL, Colucci WS: Interleukin-1 beta and tumor necrosis factor-alpha decrease collagen synthesis and increase matrix metalloproteinase activity in cardiac fibroblasts in vitro. Circ Res 2000, 86:1259-1265

21. Grinnell F: Fibroblast biology in three-dimensional collagen matrices. Trends Cell Biol 2003, 13:264-269.

22. de Hemptinne I, Gallant-Behm CL, Noack CL, Parreno J, Hart DA: Dermal fibroblasts from red Duroc and Yorkshire pigs exhibit intrinsic differences in the contraction of collagen gels. Wound Repair Regen 2008, 16:132-142.

23. Miki H, Mio T, Nagai S, Hoshino Y, Tsutsumi T, Mikuniya T, Izumi T: Glucocorticoid-induced contractility and F-actin content of human lung fibroblasts in three-dimensional culture. Am J Physiol Lung Cell Mol Physiol 2000, 278:L13-L18.

24. Schweer H, Watzer B, Seyberth HW: Determination of seven prostanoids in $1 \mathrm{ml}$ of urine by gas chromatography-negative ion chemical ionization triple stage quadrupole mass spectrometry. J Chromatogr 1994, 652:221-227. 
25. Agostini C, Gurrieri C: Chemokine/cytokine cocktail in idiopathic pulmonary fibrosis. Proc Am Thorac Soc 2006, 3:357-363.

26. Liu X, Kelm RJ Jr, Strauch AR: Transforming growth factor beta1mediated activation of the smooth muscle alpha-actin gene in human pulmonary myofibroblasts is inhibited by tumor necrosis factor-alpha via mitogen-activated protein kinase kinase 1-dependent induction of the Egr-1 transcriptional repressor. Mol Biol Cell 2009, 20:2174-2185.

27. Porter KE, Turner NA, O'Regan DJ, Ball SG: Tumor necrosis factor alpha induces human atrial myofibroblast proliferation, invasion and MMP-9 secretion: inhibition by simvastatin. Cardiovasc Res 2004, 64:507-515.

28. Theiss AL, Simmons JG, Jobin C, Lund PK: Tumor necrosis factor (TNF) alpha increases collagen accumulation and proliferation in intestinal myofibroblasts via TNF receptor 2. J Biol Chem 2005, 280:36099-36109.

29. Gallois C, Habib A, Tao J, Moulin S, Maclouf J, Mallat A, Lotersztajn S: Role of NF-kappaB in the antiproliferative effect of endothelin-1 and tumor necrosis factor-alpha in human hepatic stellate cells. Involvement of cyclooxygenase-2. J Biol Chem 1998, 273:23183-23190.

30. Mariani TJ, Arikan MC, Pierce RA: Fibroblast tropoelastin and alphasmooth-muscle actin expression are repressed by particulateactivated macrophage-derived tumor necrosis factor-alpha in experimental silicosis. Am J Respir Cell Mol Biol 1999, 21:185-192.

31. Fang Q, Liu X, Al-Mugotir M, Kobayashi T, Abe S, Kohyama T, Rennard SI: Thrombin and TNF-alpha/IL-1 beta synergistically induce fibroblastmediated collagen gel degradation. Am J Respir Cell Mol Biol 2006, 35:714-721.

32. Singer AJ, Clark RA: Cutaneous wound healing. N Eng/ J Med 1999, 341:738-46.

33. Verrecchia F, Tacheau C, Wagner EF, Mauviel A: A central role for the JNK pathway in mediating the antagonistic activity of pro-inflammatory cytokines against transforming growth factor-beta-driven SMAD3/4specific gene expression. J Biol Chem 2003, 278:1585-93.

34. Kolodsick JE, Peters-Golden M, Larios J, Toews GB, Thannickal VJ, Moore BB : Prostaglandin E2 inhibits fibroblast to myofibroblast transition via E. prostanoid receptor 2 signaling and cyclic adenosine monophosphate elevation. Am J Respir Cell Mol Biol 2003, 29:537-544.

35. Bort R, Ponsoda X, Jover R, Gomez-Lechon MJ, Castell JV: Diclofenac toxicity to hepatocytes: a role for drug metabolism in cell toxicity. $J$ Pharmacol Exp Ther 1999, 288:65-72.

doi: 10.1186/ar2902

Cite this article as: Mattyasovszky et al, The effect of the pro-inflammatory cytokine tumor necrosis factor-alpha on human joint capsule myofibroblasts Arthritis Research \& Therapy 2010, 12:R4 